\title{
Characterization and Qualitative Analysis of Some Nigerian Clay Deposits for Rafractory Applications
}

\author{
${ }^{1,2}$ D.O. Folorunso, ${ }^{3}$ P.Olubambi and ${ }^{1,2}$ J. O. Borode \\ ${ }^{1}$ Department of Metallurgical and Materials Engineering, Federal University of Technology, Akure, Nigeria \\ ${ }^{2}$ Africa Materials Science And Engineering Networks: A Carnegie-IAS (RISE) Networks \\ ${ }^{3}$ Department of Chemical and Metallurgy, Tshwane University of Technology, South Africa.
}

\begin{abstract}
The characterization of some Nigerian clay deposits has been carried out by employing fourdifferent characterization techniques. The relative proportions of the constituent compounds, the morphology and the phase identification of the different clays were determined by using X-Ray Fluorescence (XRF), Scanning Electron Microscopy/Energy Dispersive Spectroscopy (SEM/EDS), X-Ray Diffraction (XRD)and Transmission Electron Microscopy (TEM)analyses. The clays obtained from the various deposits were prepared for the analyses, using the standard procedure and the results obtained were compared to confirm the consistency and reliability of the different methods employed. The results obtained revealed the various desirable $\left(\mathrm{S}_{i} \mathrm{O}_{2}\right.$ and $\left.\mathrm{Al}_{2} \mathrm{O}_{3}\right)$ and deleterious $\left(\mathrm{Fe}_{2} \mathrm{O}_{3}, \mathrm{~K}_{2} \mathrm{O}\right.$ and $\mathrm{MgO}$ ) compounds contained in the clay samples, in the various proportions. The appropriate purification technique necessary for preparing the clays for refractory applications were therefore identified.
\end{abstract}

Keywords: characterization, clay, constituent compounds, purification and refractory.

\section{Introduction}

Clays are abundant fine earthly powders produced by the weathering and disintegration of granite and feldspathic rocks [1]. They are anhydrous complex compounds of alumina (Al2O3) and silica (SiO3) that exist in various proportions and contain varied amounts of impurities of iron, organic matters and residual minerals [2]. These clay-based materials occur both in the plain and river rine areas [1].

The term "clay" refers to a naturally occurring material that composed primarily of fine-grained minerals, which is generally plastic at appropriate water contents and susceptible to hardeningwhen fired at high temperature [3]. Although clay usually contains phyllosilicates, it may contain other materials that could impart plasticity when wet and also harden when fired. However, associated phases in clay may include organic matter and materials that do not impart plasticity [4].

Refractories are materials that can retain their strengths at high temperature and withstand chemical attack in the severe conditions of working. American Standard for Testing and Materials (ASTM C71) defines refractories as non-metallic materials having those chemical and physical properties that make them applicable for structures, or as components of systems that are exposed to environments above $538{ }^{\circ} \mathrm{C}$. They are thermal insulators and therefore used for making furnace linings, kilns, nozzles for pouring molten metal, heat exchangers and driers [5]. Applications in furnaces include primary metal melting, glass production and processing, ceramic component manufacture,heat treatment, many forms of chemical processing and testing [6].

However, earlier works on various Nigerian clay deposits have shown many of them to be unsuitable for refractory applications in the as-mined states. They are either high or low in one or more of the important refractory properties desired for good refractory works, or they are completely lacking in them[7,8,9]. The unsuitability of the local clay deposits for refractory works in the as-mined states and the desire to develop and apply them for high quality engineering works has therefore prompted the need for this work, which is principally aimed at characterizing them for appropriate purification technique.

\section{Materials And Method}

Five Clay samples from five different clay deposits in different parts of the South - Western part of Nigeria were prepared for X-ray Diffraction (XRD), X-ray Fluorescence (XRF), Transmission Electron Microscopy (TEM) and Scanning Electron Microscopy (SEM) analyses, in accordance to the standard procedure. The clays were those from Iseyin in Oyo State, Ipetumodu in Osun State, Ifon in Ondo State, IgbaraOdo and Isan in Ekiti State. $99.8 \%$ purity oxalic acid obtained from SMM Instruments, South Africa was also used in the leaching of the clays. The analyses were carried out to investigate the mineralogical composition, relative proportions of the constituent compounds, the morphology and the phase identification of the five prepared samples from the clay deposits. 


\subsection{X-ray Diffraction (XRD) Analysis}

Representative samples of the clays were separately crushed and milled to fine particles. The mineral phases within the samples were identified by powdered X-ray diffractometry method. The samples were first subjected to X-ray scanning using the Philips PW 1830 X-ray diffractometry with a cu-anode. After the X-ray scanning of the samples, mineral peaks were identified using XPert High Score plus Software. The background and peak-positions were identified and based on the peak positions and intensities, a search-match routine was performed.

\subsection{X-ray Fluorescence (XRF) Spectroscopy Analysis}

Quantitative analysis of the major minerals within the samples was done by X-ray Fluorescence Spectroscopy using a Magi X Pro XRF Spectrometer. For this purpose, a mass of $8 \mathrm{~g}$ of each of the powdered clay samples was mixed with $2 \mathrm{~g}$ of Herzog organic binder. The organic binder contained $90 \%$ cellulose and $10 \%$ wax. The mix was further ground and homogenized using a mill. The homogenized samples were placed in an aluminum cup and hydraulically pressed into pellets under very high pressure of 20 tones for 60 seconds. This was done to ensure sample integrity under the vacuum and a consistent surface to receive the X-rays.

\subsection{Scanning Electron Microscopy (SEM) Analysis}

Morphological, quantitative and qualitative analyses of the clay samples were carried out using SEM model JEOL 840. The SEM studies for the mineral analysis of representative samples were conducted in two stages. All the samples were carbon coated in order to make the minerals surface conductive. In the first stage, which was aimed at examining the minerals morphology and identifying their mode of occurrence, crushed carbon coated minerals were examined directly with scanning electron microscopy without polishing. The second stage of the microscopic study was aimed at identifying the mineral phases present within the samples. Qualitative chemical analysis of minerals was carried out on the clay samples to produce Backscattered images (BSI). The Quantitative analysis was carried out using the EDX analysis.

\subsection{Transmission Electron Microscopy (TEM)}

Consequent upon the understanding that, the presence of iron oxide $\left(\mathrm{Fe}_{2} \mathrm{O}_{3}\right)$ in clay is detrimental to the clay's effective performance as a good refractory material, it then became imperative to reduce it to an acceptable level of less than $1 \%[8,10]$ by leaching with oxalic acid.

Three of the clays that had the least quantities of Fe (Ifon, Ipetumodu and Iseyin clays) as shown in Table 2, which were most likely to perform better as refractory materials were defferated via leaching with oxalic acid. The leached clays and the raw ones were prepared for TEM study by dispersing them in alcohol. The samples were in turn placed on a carbon-coated metal grid which gives preferred orientation and allows observation of clay flakes and then examined with TEM equipped with the same microanalysis electron microscope. Various magnifications were used to obtain suitable micrographs of the clay minerals and this allowed for direct measurement of the several dimensions of the particles and thus also the shape of the particles.

\section{Results And Discussion}

\subsection{X-Ray Diffraction (XRD) Analysis}
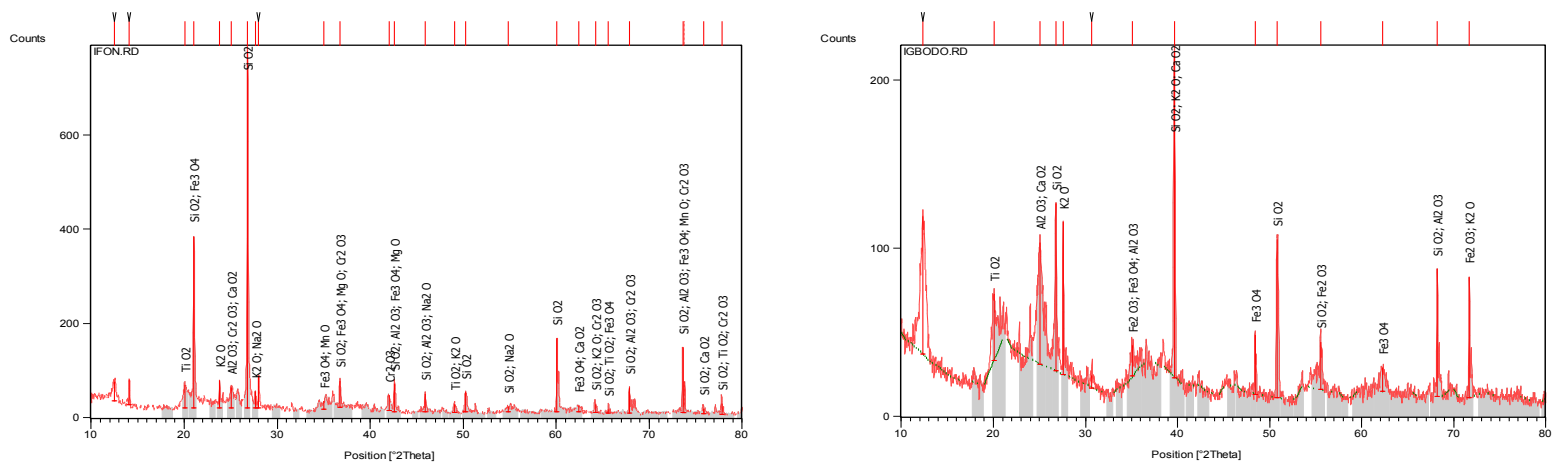

Figure 1: X-ray diffraction pattern of Ifon clay Figure 2: X-ray diffraction pattern of Igbara-Odo clay 


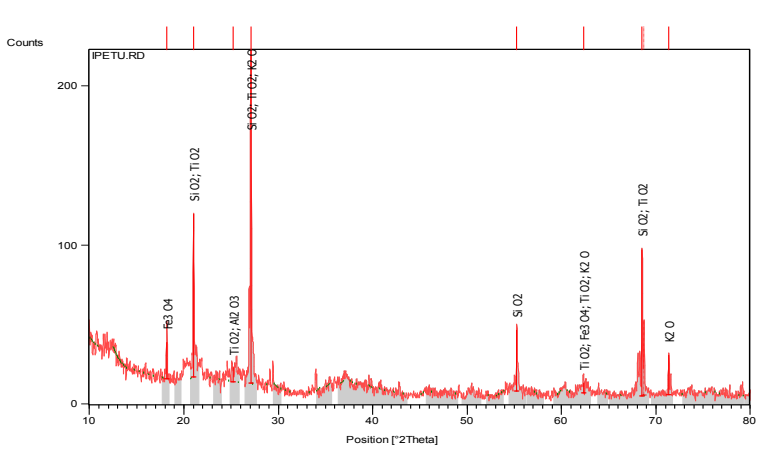

Figure 3: X-ray diffraction pattern of Ipetumodu clay clay

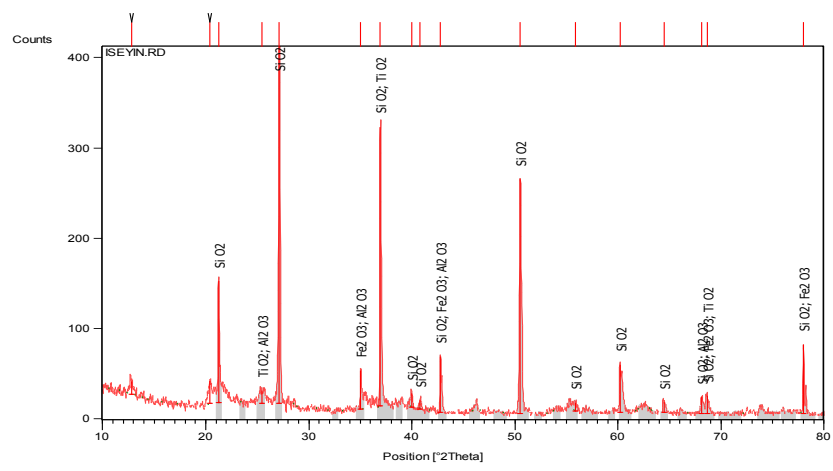

Figure 5: X-ray diffraction pattern of Iseyin clay

Table 1: XRD Quantitative Analysis of Raw and Processed Clays

\begin{tabular}{|c|c|c|c|c|c|c|}
\hline \multirow{2}{*}{ Clay Minerals } & \multicolumn{4}{|c|}{ \% Weight of Clay Minerals Before and after Processing } \\
\cline { 2 - 7 } & \multicolumn{2}{|c|}{ Ifon Clay } & \multicolumn{2}{c|}{ Ipetumodu Clay } & \multicolumn{2}{c|}{ Iseyin Clay } \\
\cline { 2 - 7 } & Raw & Leached & Raw & Leached & Raw & Leached \\
\hline Kaolinite & 5.73 & 9.60 & 20.02 & 38.53 & 39.71 & 36.33 \\
\hline $\begin{array}{c}\text { Muscovite/ } \\
\text { Illite }\end{array}$ & 3.81 & 4.70 & 15.02 & 25.71 & 14.66 & 20.75 \\
\hline Quartz & 41.42 & 37.78 & 23.84 & 16.74 & 39.45 & 36.11 \\
\hline Microcline & 30.90 & 35.20 & 26.10 & 7.65 & 3.10 & 3.38 \\
\hline Plagioclase Albite & 18.14 & 12.70 & 15.02 & 11.36 & 3.08 & 3.43 \\
\hline TOTAL & 100.00 & 99.98 & 100.00 & 99.99 & 100.00 & 100.00 \\
\hline
\end{tabular}

The diffractograms (Fig 1-5) show the X-ray diffraction pattern of the as-received five clay samples. Careful investigation reveals that the samples were composed essentially of $\mathrm{S}_{\mathrm{i}} \mathrm{O}_{2}, \mathrm{Al}_{2} \mathrm{O}_{3}, \mathrm{Fe}_{2} \mathrm{O}_{3}$ and to very limited extent of $\mathrm{K}_{2} \mathrm{O}$ and $\mathrm{MgO}$. Some other oxides were also present but in very negligible proportions.

\subsection{X-Ray Fluorescence (XRF)}

The results of the X-ray Fluorescence semi-quantitative analysis of the elements in the clay samples are as shown in TABLE 2 . 
Table 2: XRF semi-quantitative analysis of the elements

\begin{tabular}{|l|c|c|c|c|c|}
\hline Constituents & $\begin{array}{c}\text { Ifon Clay } \\
(\%)\end{array}$ & $\begin{array}{c}\text { Igbara-Odo Clay } \\
(\%)\end{array}$ & $\begin{array}{c}\text { Ipetumodu Clay } \\
(\%)\end{array}$ & $\begin{array}{c}\text { Isan Clay } \\
(\%)\end{array}$ & $\begin{array}{c}\text { Iseyin Clay } \\
(\%)\end{array}$ \\
\hline $\mathrm{Al}_{2} \mathrm{O}_{3}$ & 22.42 & 25.737 & 25.03 & 23.98 & 22.729 \\
\hline $\mathrm{SiO}_{2}$ & 63.35 & 56.636 & 59.482 & 54.657 & 62.292 \\
\hline $\mathrm{Fe}_{2} \mathrm{O}_{3}$ & 6.109 & 9.226 & 8.652 & 10.408 & 7.266 \\
\hline $\mathrm{K}_{2} \mathrm{O}$ & 2.878 & 2.94 & 1.259 & 2.513 & 1.36 \\
\hline $\mathrm{MgO}$ & 1.351 & 1.166 & 0.91 & 2.401 & 0.985 \\
\hline $\mathrm{Ba}$ & 0.092 & 0.102 & 0.083 & 0.08 & 0.065 \\
\hline $\mathrm{CaO}$ & 0.689 & 0.911 & 0.763 & 0.843 & 0.541 \\
\hline $\mathrm{Cl}$ & ---- & 0.016 & 0.015 & 0.028 & 0.026 \\
\hline $\mathrm{Co}$ & ---- & 0.025 & 0.017 & 0.08 & 0.034 \\
\hline $\mathrm{Cr} \mathrm{O}_{3}$ & 0.046 & 0.05 & 0.045 & 0.036 & 0.043 \\
\hline $\mathrm{Cu}$ & 0.021 & 0.034 & 0.026 & 0.137 & 0.046 \\
\hline $\mathrm{MnO}^{\mathrm{Na}}$ & 0.117 & --- & 0.045 & 0.109 & 0.05 \\
\hline $\mathrm{Na}_{2} \mathrm{O}$ & 0.789 & 1.229 & 0.372 & 0.604 & 0.259 \\
\hline $\mathrm{Ni}$ & 0.064 & 0.042 & 0.078 & 0.061 & 0.074 \\
\hline $\mathrm{P}_{2} \mathrm{O}_{5}$ & 0.109 & 0.051 & 0.047 & 0.049 & 0.058 \\
\hline $\mathrm{SO}_{3}$ & 0.047 & 0.026 & 0.028 & 0.016 & 0.123 \\
\hline $\mathrm{Sr}_{\mathrm{TiO}}$ & 0.019 & ---- & 0.019 & 0.015 & 0.008 \\
\hline $\mathrm{Zr}$ & 0.923 & 0.895 & 1.512 & 1.577 & 1.046 \\
\hline $\mathrm{Total}$ & 0.045 & 0.02 & 0.103 & 0.028 & 0.056 \\
\hline & 99.1 & 99.07 & 98.526 & 97.7 & 97.1 \\
\hline
\end{tabular}

The results show that sample A contains the highest amount of silica by mass of $63.35 \%$, followed by sample E with $62.29 \%$ and with sample D having the least, 54.66\%. Sample B contains the highest amount of Alumina, $25.74 \%$ followed by sample C with $25.03 \%$ while sample A contains the least with $22.42 \%$. sample D indicated the highest amount of Ferric oxide, $10.41 \%$, closely followed by sample B with $9.23 \%$ while sample A contains the least with just $6.11 \%$. sample B has the greatest quantity of $2.94 \%$ by mass of potassium oxide, followed by sample A with $2.88 \%$ while sample $\mathrm{C}$ contains the least amount of just $1.26 \%$. So also, sample D contains the highest amount of magnesium oxide, $2.40 \%$ followed by sample A with $1.35 \%$ while sample $\mathrm{C}$ contains the least with just $0.91 \%$. All other minerals present are in such negligible proportion that their presence would not constitute threats to the performances of the clay as refractory materials.

\subsection{Scanning Electron Microscopy (SEM)}
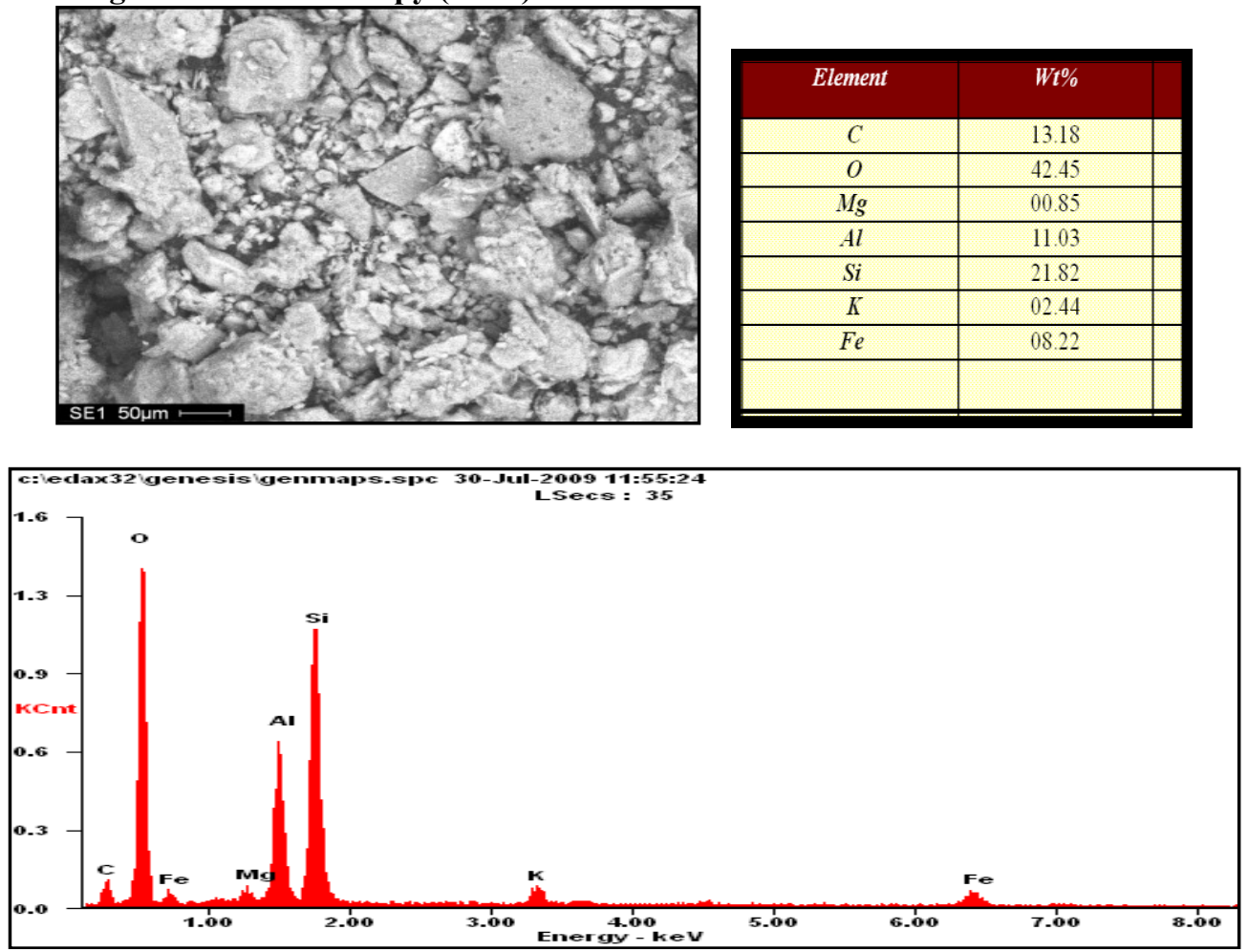

Figure 6: Typical SEM/EDS Micrographs of Ifon Clay Showing the Morphology of the Clay and its Chemical Composition 


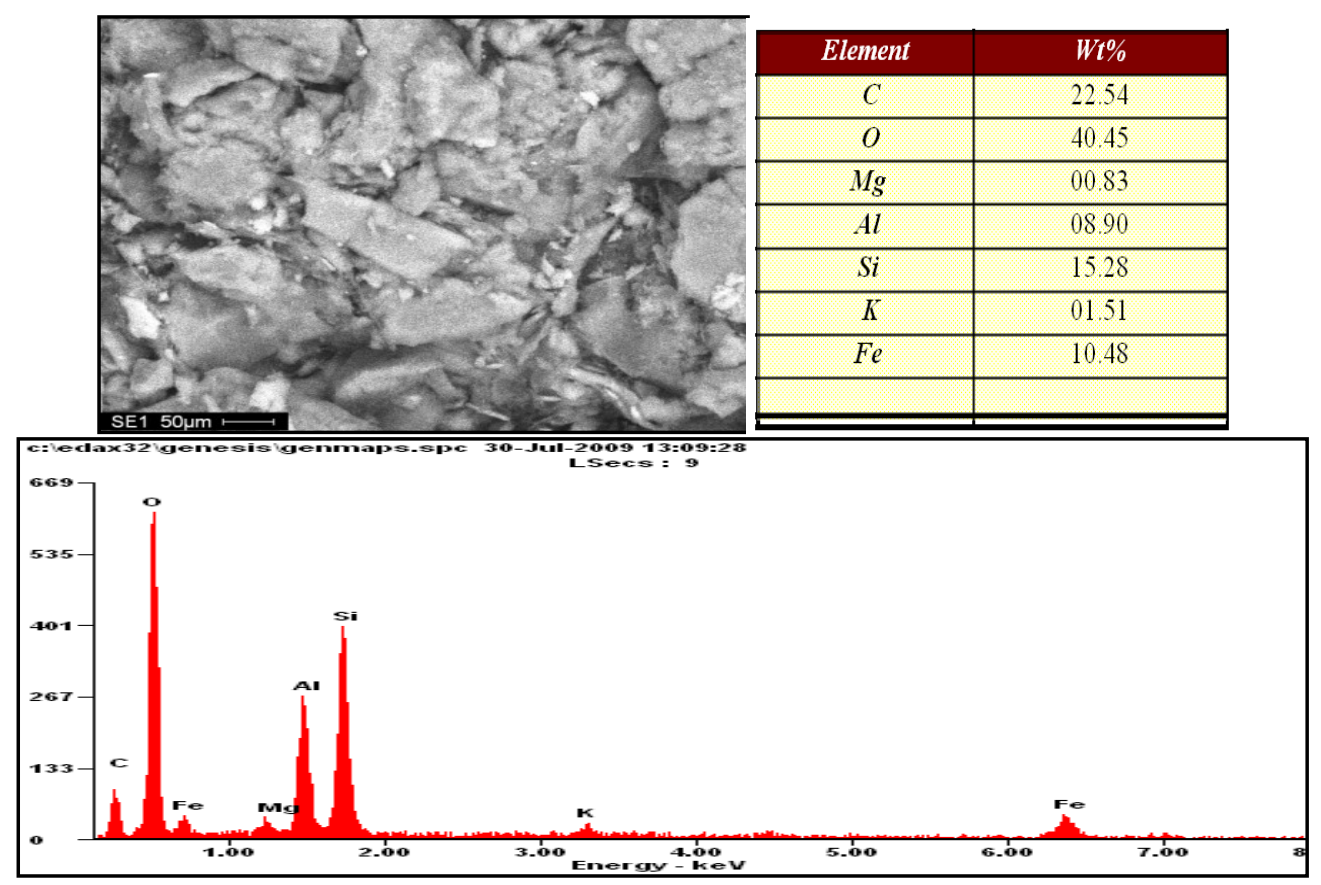

Figure 7: Typical SEM/EDS Micrographs of Igbara-Odo Clay Showing the Morphology of the Clay and its Chemical Composition

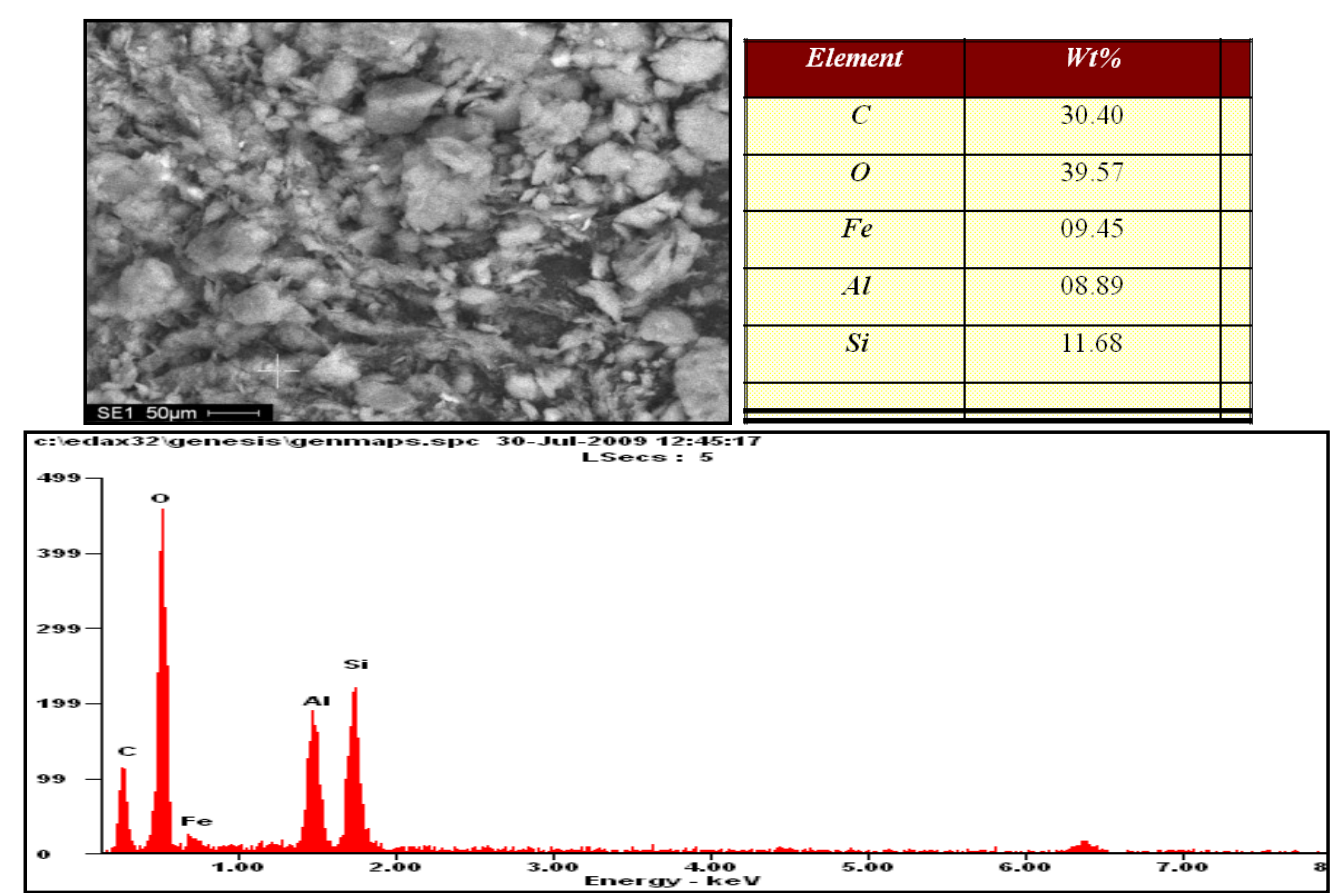

Figure 8: Typical SEM/EDS Micrographs of Ipetumodu Clay Showing the Morphology of the Clay and its Chemical Composition

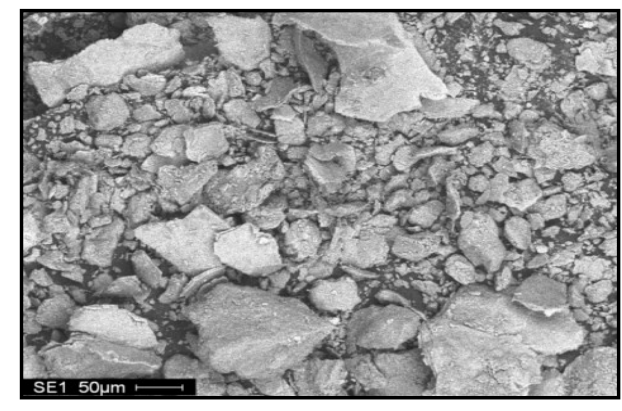

\begin{tabular}{|c|c|c|}
\hline Element & Wt\% & \\
\hline$C$ & 22.41 & \\
\hline$O$ & 41.42 & \\
\hline$M g$ & 01.08 & \\
\hline$A l$ & 08.81 & \\
\hline$S i$ & 15.24 & \\
\hline$K$ & 02.12 & \\
\hline$F e$ & 08.92 & \\
\hline
\end{tabular}




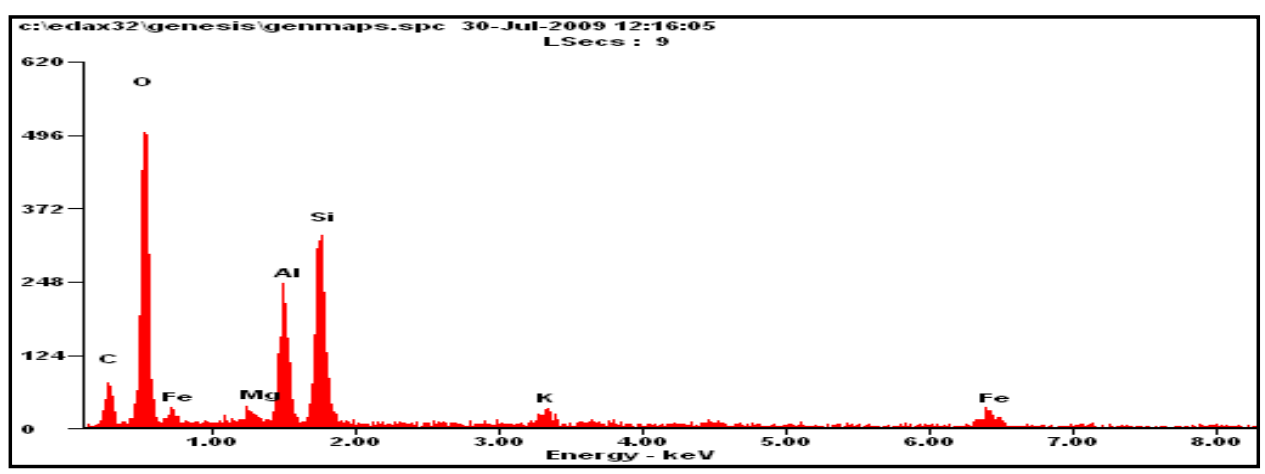

Figure 9: Typical SEM/EDS micrographs of Isan Clay showing the morphology of the clay and its chemical composition

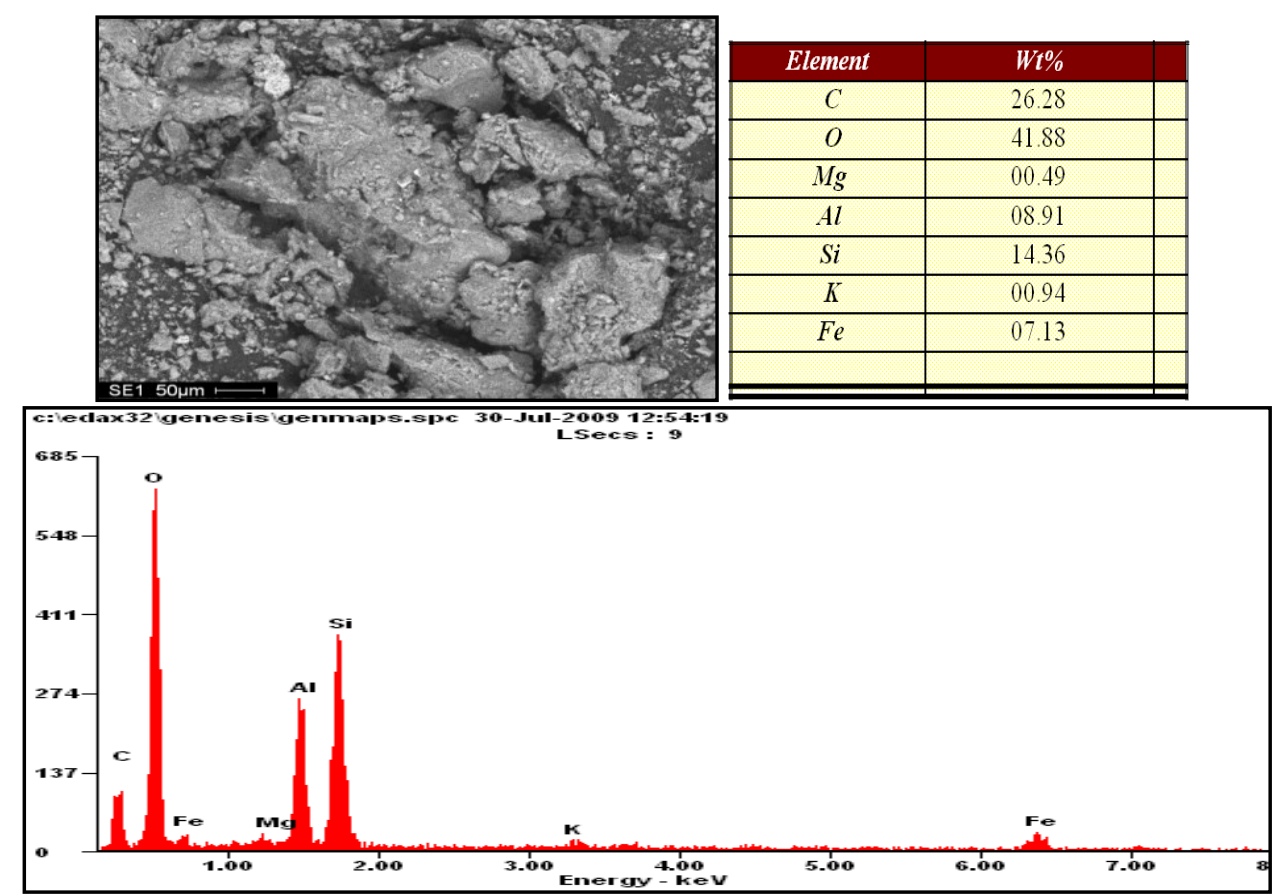

Figure 10: Typical SEM/EDS Micrographs of Iseyin Clay Showing the Morphology of the Clay and its Chemical Composition.

Fig. 6-10 are the results of the SEM/EDS analysis for all the five clay samples, which show the SEM micrographs of the relative sizes of the clay particles at X500 magnification, chemical compositions at both general surfaces and selected areas and the spectra depicting the peaks of the elements present.

TABLE. 3 shows the EDS analysis for elemental chemical composition. The analysis shows the actual percentages of the various elements contained in the clays. The EDS analysis revealed very reasonable similarities in results, with those of XRD and XRF.

Table 3: EDS Chemical Analysis of the Five Clay Samples

\begin{tabular}{|l|c|c|c|c|c|c|c|}
\hline Clay Samples & $\mathrm{C}$ & $\mathrm{O}$ & $\mathrm{Mg}$ & $\mathrm{Al}$ & $\mathrm{Si}$ & $\mathrm{K}$ & $\mathrm{Fe}$ \\
\hline Ifon & 13.18 & 42.45 & 00.85 & 11.03 & 21.82 & 02.44 & 08.22 \\
\hline Igbara-Odo & 22.54 & 40.45 & 00.83 & 08.90 & 15.28 & 01.51 & 10.48 \\
\hline Ipetumodu & 30.40 & 39.57 & - & 08.89 & 11.68 & - & 09.45 \\
\hline Isan & 22.41 & 41.42 & 01.08 & 08.81 & 15.24 & 02.12 & 08.92 \\
\hline Iseyin & 26.28 & 41.88 & 00.49 & 08.91 & 14.36 & 00.94 & 07.13 \\
\hline
\end{tabular}


3.4 Transmission Electron Microscopy (TEM)

The results of the TEM analysis are as presented in Fig. 11-13.

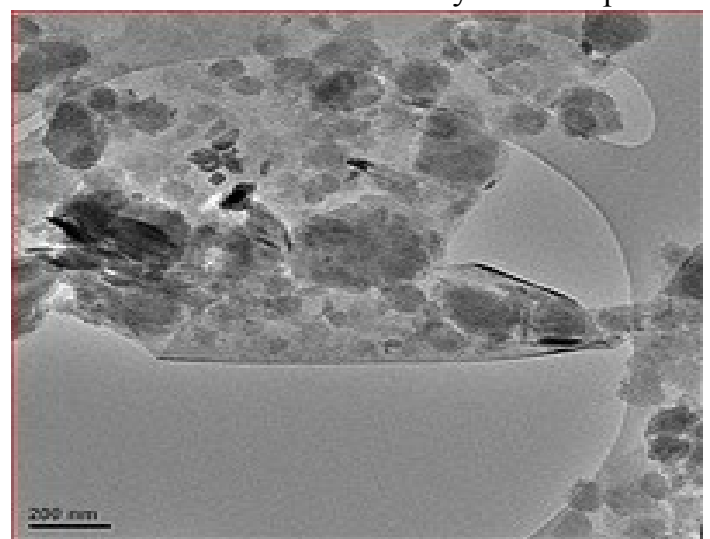

(a) Raw Clay before defferation

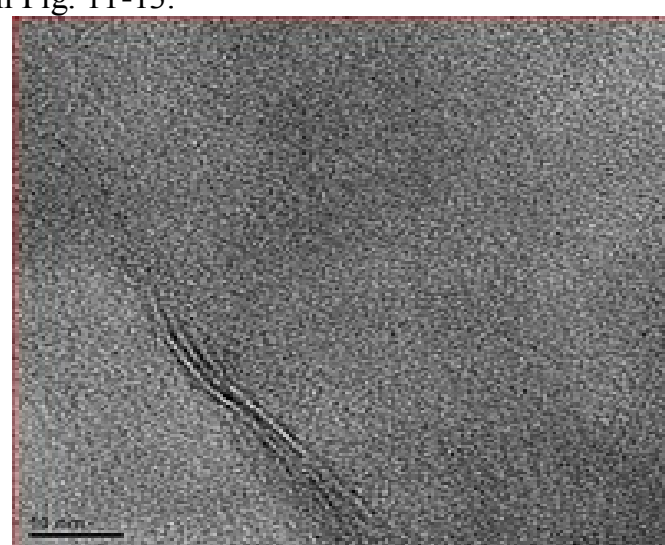

(b) Clay after defferation

Figure 11: Transmission Electron Micrographs (TEM) of Raw and Leached Ifon Clay

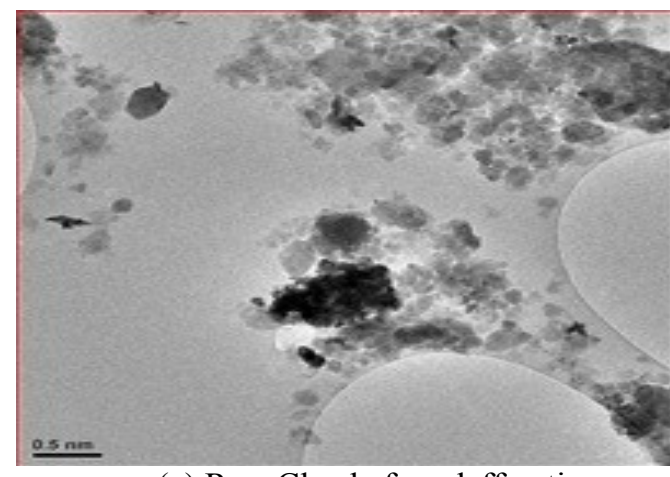

(a) Raw Clay before defferation

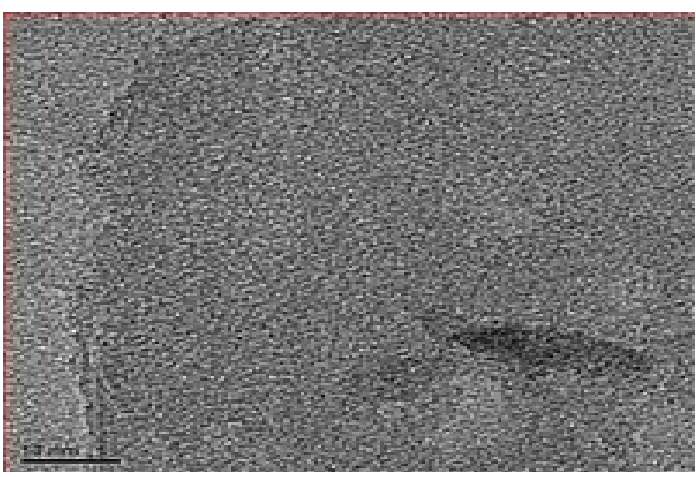

(b) Clay after defferation

Figure 12: Transmission Electron Micrographs (TEM) of Raw and Leached Ipetumodu Clay

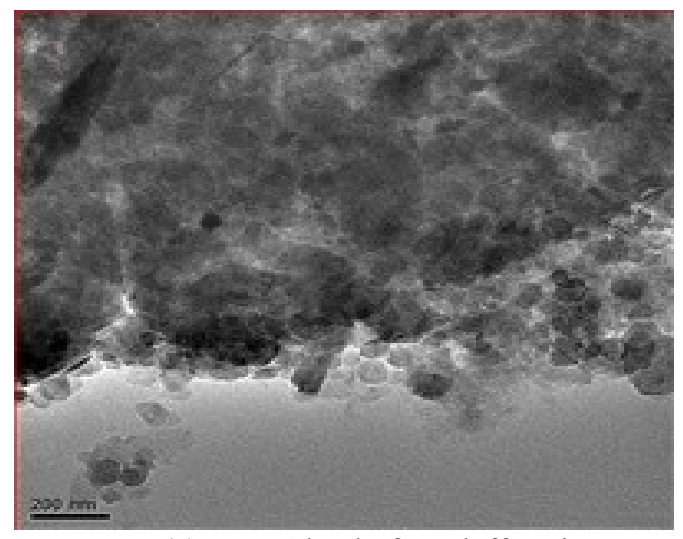

(a) Raw Clay before defferation

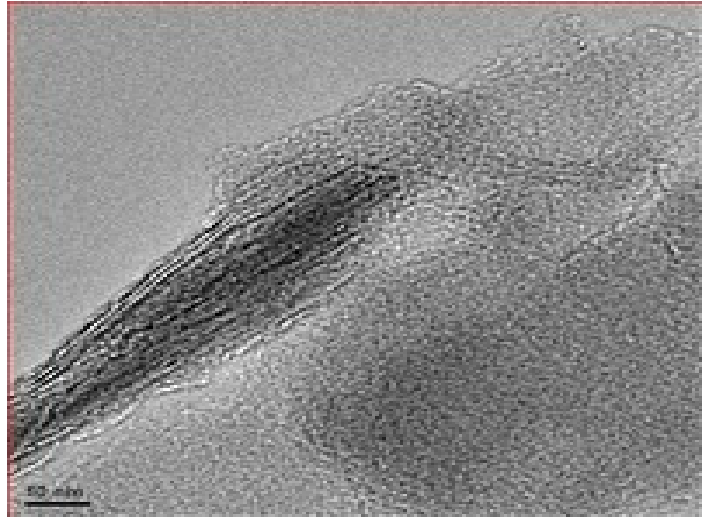

(b) Clay after defferation

Figure13: Transmission Electron Micrographs (TEM) of Raw and Leached Iseyin Clay

Figures 11 to 13 are the transmission electron micrographs of the defferated and raw samples of Ifon, Ipetumodu and Iseyin clays respectively. They all show the distribution of the minerals present in them. The minerals occurred as agglomerates in the unprocessed clays but after undergoing the defferation process, they became finely and uniformly distributed in the bulk. The uniform dispersion of the minerals in the processed clays enabled the oxalic acid to make direct contacts with virtually all the grains in the clays and hence able to remove the iron present in them. The dark portions indicate the impurity levels of the various clays. Fig.12 shows the least quantity of dark portions while Fig.13 shows the highest quantity of the dark portions, meaning that Ipetumodu clay responded best to the defferation exercise while Iseyin clay exhibited the least response. 


\section{Conclusion}

The combination of the four characterization techniques adopted in this study (XRD, XRF, TEM and SEM/EDS) showed consistency in the revelation of the quantities of different constituents of the clays. The chemical analyses show that clay is mainly constituted by alumina and silica in major quantities and oxides of iron, calcium, magnesium and other elementsin minor quantities. X-ray diffraction study shows the presence of quartz, kaolinite, hematite, illites and tridymite as major phases.

Information from the mineralogy of these clays suggests that appropriate hydrometallurgical procedure could be adopted in purifying them. The clays after purification exhibited the potential for application in the production of refractories.

\section{Acknowledgements}

The authors wish to express profound gratitude to the following bodies for their support for the research work: The Federal University of Technology, Akure (FUTA), African Materials Science and Engineering Network (AMSEN), Regional Initiatives in Science and Education (RISE), Science Initiative Group (SIG), Vesuvius South Africa and Tshwane University of Technology (TUT), South Africa for their financial supports and access to the equipment used during the course of the research.

\section{References}

[1] E.S. Nweke and E.I. Ugwu,Analysis and Characterization of Clay Soil in Abakaliki, Nigeria, The Pacific Journal of Science and Technology, v. 8, n.2, 2007, 190-193.

[2] J. F. Akinfolarin and O. O. Awopetu,The Effect of Sawdust on the Insulating Effect of Ikere Clay as Refractory Lining, AU J.T. 17(3), 2014, 143-147.

[3] C. P. Dogan, K. S.Kwong and J. P.Bennet, "Improved refractory materials for Slagging coal Gasifiers, "in proceedings from the $27^{\text {th }}$ International conference on coal utilization and fuel systems, Clearwater, Florida. 2002.

[4] W.T. Bakker, "Refractories for present and future electric power plants", Key Engineering Materials, Trans Tech Publications, Vol. $88,1993,41-70$

[5] S.B. Hassan, "Effect of silicon carbide on some refractory properties of Kankara clay", Proceedings of Nigerian Metallurgical Society, 2001.

[6] T. Azom, "Refractories-An overview", Journal of materials online at www.azom.com, 2008

[7] J. O. Borode, O. O. Onyemaobi and J. A. Omotoyinbo, Suitability of some Nigerian clays as refractory raw materials, Nigerian Journal of Engineering Management, Vol. 3, 2000, 14-18.

[8] D. O. Folorunso, P. A. Olubambi and J. O.Borode, Effect of Alumina cement on the refractory properties of leached Ipetumodu clay, Leonardo electronic journal of practices andTecnologiesIss. 20, 2012b, 25-38.

[9] S. B. Hassan, "Refractory Properties of Bauchi and Onibode Clays of Nigeria for Furnace Linning",African Journal of Science and Technology, Vol.1. No. 1, 2000, 33-41.

[10] C. N. Mulligan, M. Kamali, andB. F. Gibbs,Bioleaching of heavy metals from low-grade mining ore using Aspergillus niger. J. Hazard Mater., 110, 2004, 77-84. 